\title{
ASSESSMENT OF PATH COEFFICIENT ANALYSIS OF YIELD AND \\ IT'S ASSOCIATED TRAITS IN WHEAT
}

\section{CHITRALEKHA SHYAM, P. K. CHANDRAKAR, UMAKANT BANJARE}

\author{
N. K. RASTOGI \& SATYAPAL SINGH
}

Department of Genetics and Plant Breeding, Indira Gandhi Krishivishwavidyalaya, Raipur (C.G.), India

\begin{abstract}
Wheat is an important cereal crop of cool climates, and plays an important role in the food and nutritional security of India. The experiment was conducted at Research Farm, IGKV, Raipur during Rabi 2013-14. Twenty two wheat genotypes including checks were grown in Randomized Block Design with three replications. Five randomly selected plants from each treatment were tagged for recording the observations. The objective of this study was to establish path coefficient analysis in wheat. Yield is a complex trait, which is interacted by number of components directly or indirectly. The present experiment was conducted and estimates of Path coefficient analysis. Path coefficient analysis revealed that number of seeds per spike, 1000-seed weight, biological yield per plot, spike length and days to $50 \%$ flowering exhibited a high positive direct effect and significant correlation coefficient with seed yield per plant. Therefore direct selection through these traits will be effective for yield improvement in seed yield. Plant height and days to maturity had negative direct effect as well as significant negative correlation with seed yield per plant. Therefore, it is logical to select plants having short plant height and early maturity for the improvement of seed yield per plant.

KEY WORDS: Agro-Morphological Traits, Grain Yield, Path Coefficient Analysis \& Wheat
\end{abstract}

Received: Jan 01, 2018; Accepted: Jan 20, 2018; Published: Mar 05, 2018; Paper Id.: IJBRAPR20181

\section{INTRODUCTION}

Wheat is the most important food crop of India, and is a main source of protein and energy. Globally, the total area under cultivation of wheat in 2013-14 is 227 million hectares, production of wheat recorded 654 million tonnes and productivity was recorded as 3 tonnes per hectare. The highest production recorded 125.6 milliontonnes in China during 2013-14 and it ranks first in the world. India ranks second with a record production by 93.51 million tonnes (Anonymous, 2014 a). Major wheat producing countries of the world are China, India, United state of America, France, Russia, Canada, Germany, Turkey, Australia, Ukraine and Pakistan. India also has the larger area under wheat. About 90 percent of total wheat production is contributed by five states viz., Uttar Pradesh, Punjab, Haryana, Madhya Pradesh and Rajasthan. The other wheat producing states are Bihar, Gujarat, Jammu and Kashmir, Maharashtra, West Bengal and Chhattisgarh. The area, under wheat in India during 2000 to 2014 is increased from 25.73 to 30.00 million hectare where, production from 69.68 to 93.51 million tonnes and productivity from 27.08 to 31.71 quintals per hectares (Anonymous, $2014 \mathrm{~b}$ ). The annual growth rate for area, production and yield per hectare shows that the rate of increasing in area under wheat was highest during 2011-12 that is 1.31 percent and least during 2002-03 that is 1.30 percent. The average increase in the growth rate of area under wheat during 2000 to 2014 is 1.30 percent in India (Anonymous, 2014 a). The average growth rate in the production and yield per hectare during 2000-2014 is 3.7 and 3.9 percent, respectively. Uttar Pradesh ranks first, 
production of wheat with record of 30.30 metric tonnes among the wheat growing states of the country, followed by Punjab (16.11) and Madhya Pradesh (13.13) metric tonnes (Anonymous, 2013). Chhattisgarh is located in the east - central part of the country between $17^{\circ} 14^{\prime} \mathrm{N}$ and $24^{\circ} 45^{\prime} \mathrm{N}$ latitudes and $73^{\circ} 30^{\prime} \mathrm{E}$ and $84^{\circ} 15^{\prime} \mathrm{E}$ longitudes, whereas Raipur the capital of the Chhattisgarh state, lies at $21^{\circ} 16^{\prime} \mathrm{N}$ latitude and $81^{\circ} 36^{\prime} \mathrm{E}$ longitude with an altitude of 289.60 meters above sea level. Wheat is used in the form of chapatti, bread, naan, tandoori, rumali, roti, puri, pudding, bhatore, bran and fodder etc. (Singh etal., 2013). Wheat offers a great wealth of material for genetical studies due to its wide ecological distribution and enormous variation encountered for various morphological and physiological characters (Rangareet al., 2010). In India, it is mainly grown under three production conditions, viz., timely sown; medium to good fertility, irrigated; late sown, medium fertility; irrigated and timely sown; low fertility and in rainfed conditions (Dattaet al., 2009). The grain yield and yield components of wheat are affected very much by the genotype and the environment. Therefore, as new cultivars are being produced by breeding, the relationships between yield and its components are studied by the breeders. To increase the yield, study of direct and indirect effects of yield components provides the basis for its successful breeding programme and hence the problem of yield increase can be more effectively tackled on the basis of performance of yield components and selection for closely related characters (Choudhryet al., 1986). The objective of this study was to establish path coefficient analysis. The path analysis was originally developed by Wright (1921) and elaborated by Dewey and Lu (1959). Path coefficient analysis splits the genotypic correlation coefficient into measures of direct and indirect effects. It measures the direct and indirect contribution of independent variables on dependent variable.

\section{MATERIALS AND METHODS}

Twenty two wheat genotypes including check varieties were used in this study. All the twenty two genotypes were grown in Randomized Block Design with three replications during Rabi 2013-14 at the Instructional cum Research Farm, Indira Gandhi KrishiVishwavidyalaya, Raipur. In each replication, twenty two treatments were grown in 10 rows, 5 $\mathrm{m}$ long and $20 \mathrm{~cm}$ apart. The crop was provided with protective irrigations and recommended doses of fertilizers. The average maximum and minimum temperature at Raipur ranges between $31.82^{\circ} \mathrm{C}$ and $16.89^{\circ} \mathrm{C}$, respectively during crop growth period. December was coldest month in Chhattisgarh during 2013 - 2014. Five randomly selected plants from each treatment were tagged for recording the observations on the following characters, viz., Days to $50 \%$ flowering, Days to maturity, Plant height, Number of tillers per plant, Spike length, Number of spikelets per spike, Number of seeds per spikelet, Number of seeds per spike, Number of seeds per plant, 1000-seed weight, Seed yield per plant, Biological yield per plot, Seed yield per plot and Harvest Index. Path coefficient analysis partitioned the observed genotypic and phenotypic correlation coefficients between yield and its component in direct and indirect effects. The selection of the traits contributing directly to the yield will be beneficial for the breeder in changing the genetic architect of the crop plant for promoting the yield potential of the crop. If a character $\mathrm{Y}$ is determined by correlated character $\mathrm{X} 1, \mathrm{X} 2$ and $\mathrm{X} 3$ a path diagram may be formulated. Thus we get a set of simultaneous equations as below:

$$
\begin{aligned}
& R(\mathrm{x} 1, \mathrm{y})=\mathrm{a}+r(\mathrm{x} 1, \mathrm{x} 2) \mathrm{b}+r(\mathrm{x} 1 \mathrm{x} 3) \mathrm{c} \\
& R(\mathrm{x} 2, \mathrm{y})=r(\mathrm{x} 2, \mathrm{x} 1) \mathrm{a}+\mathrm{b}+r(\mathrm{x} 2 \times 3) \mathrm{c} \\
& R(\mathrm{x} 3, \mathrm{y})=r(\mathrm{x} 3, \mathrm{x} 1) \mathrm{a}+r(\mathrm{x} 3 \times 2) \mathrm{b}+\mathrm{c}
\end{aligned}
$$

The simultaneous equations given above can be presented in matrix notation as 
$\left[\begin{array}{l}r\left(x_{1}, y\right) \\ r\left(x_{2}, y\right) \\ r\left(x_{3}, y\right)\end{array}\right]=\left[\begin{array}{lll}r x_{1} x_{1} & r x_{1} \cdot x_{2} & r \cdot x_{1} x_{3} \\ r x_{2} x_{1} & r x_{2} x_{2} & r x_{2} x_{3} \\ r x_{3} x_{1} & r x_{3}, x_{2} & r x_{3} x_{3}\end{array}\right]\left[\begin{array}{l}a \\ b \\ c\end{array}\right]$

$\begin{array}{lll}\text { A } & \text { B } & \text { C }\end{array}$

Where,

rxly $=$ genetic correlation coefficient between character $\mathrm{x} 1 \mathrm{y}$

$r x 2 y=$ genetic correlation coefficient between character $\mathrm{x} 2 \mathrm{y}$

$r x 3 y=$ genetic correlation coefficient character $\mathrm{x} 3 \mathrm{y}$

$a=$ direct effect of $\mathrm{x} 1$ on $\mathrm{y}$

$b=$ direct effect of $\mathrm{x} 2$ on $\mathrm{y}$

$c=$ direct effect of $\mathrm{x} 3$ on $\mathrm{y}$

The solution for vector $\mathrm{C}$ may be obtained as follows :

$\mathrm{A}=\mathrm{BC}$

$\mathrm{C}=\mathrm{B}-1 . \mathrm{A}$

Where,

B-1 = inverse of matrix of B.

After calculation the value of path coefficient i.e. 'C' vector the residual effect was estimated by the method suggested by Singh and Chaudhary (1985)

Residual effect $=\sqrt{ } 1-$ di. rxixj

Where,

$d i=$ direct effect of ith character

rxixj= correlation coefficient of ith character with $\mathrm{jth}$ character

\section{RESULTS AND DISCUSSIONS}

\section{Path Coefficient Analysis}

Plant analysis is the effective statistical tool to determine the direct and indirect contributions of different characters towards yield. Path coefficient analysis is simply a standardized partial regression coefficient, which splits the correlation coefficient into direct and indirect effects. In other words, it measures the direct and indirect contribution of various independent characters on a dependent character. This technique was originally developed by Wright (1921) and was used for the first time in plant by Dewey and Lu (1959). In general, the genotypic, direct effects as well as indirect effects were slightly higher in magnitude as compared to phenotypic direct and indirect effects. If the correlation between yield and a character is due to direct effect of a character, it reveals true relationship between them and direct selection for this trait will be rewarding for yield improvement. However, if the correlation coefficient is mainly due to indirect effects 
of the character through another component trait, indirect selection through such trait will be effective in yield improvement. If the direct effect is positive and high, but the correlation is negative, in such situation direct selection for such trait should be practiced to reduce the undesirable indirect effect.

\section{Genotypic Path Coefficient Analysis}

The genotypic path coefficients have been presented in Table 1. At genotypic level considering seed yield per plant as dependent character maximum positive direct effect is from number of seeds per spike (3.327) followed by 1000seed weight (1.758), spike length (1.735), biological yield per plot (0.677) and days to $50 \%$ flowering $(0.28)$ whereas negative direct effect on seed yield per plant via plant height (-3.259), number of seeds per plant (-3.160), harvest index (1.349), days to maturity (-0.868), number of seeds per spikelet (-0.542), number of spikelets per spike $(-0.271)$, seed yield per plot (-0.187) and number of tillers per plant (-0.052). Number of seeds per spike exhibited a high positive direct effect and highly significant correlation coefficient with seed yield per plant, indicating the true relationship. Therefore, direct selection through this trait will be effective for yield improvement in seed yield per plant. Direct effect of number of seeds per plant with seed yield per plant was negative however, the correlation coefficient was positive due to the positive indirect effect via., number of seeds per spike, plant height, biological yield per plot, days to maturity, 1000-seed weight, number of spikelets per spike and number of tillers per plant. Since the direct effect was negative, so the direct selection for these traits to improve yield will be undesirable. However, improvement in number of seeds per spike, plant height, biological yield per plot, days to maturity, 1000- seed weight, number of spikelets per spike and number of tillers per may help compensate the negative effect of number of seeds per plant. Direct effect of days to $50 \%$ flowering was negligible and its correlation with seed yield per plant was negative and significant, so that, the selection for these traits will not be effective.

The indirect effect had been explained for only those characters which had shown significant correlation values with seed yield per plant. Number of seeds per spikelet exhibited positive indirect effect on seed yield per plant through number of seeds per spike (1.621), days to maturity (0.638), harvest index (0.430), spike length (0.320), biological yield per plot (0.205) and number of spikelets per spike (0.055), but negative indirect effect via number of seeds per plant ($1.289)$, plant height (-0.419), days to $50 \%$ flowering $(-0.205), 1000$-seed weight (-0.136), seed yield per plot (-0.032) and number of tillers per plant (-0.017). Number of seeds per spike showed positive indirect effect on seed yield per plant through spike length (0.568), plant height (0.488), biological yield per plot (0.225) and days to maturity (0.05) but negative indirect effect via., number of seeds per plant (-2.531), 1000-seed weight (-0.746), number of seeds per spikelet (-0.264), harvest index (-0.178), days to $50 \%$ flowering $(-0.119)$, seed yield per plot $(-0.066)$, number of tillers per plant $(-0.014)$ and number of spikelets per spike (- 0.014). Number of seeds per plant exhibited positive indirect effect on seed yield per plant through number of seeds per spike (2.664), plant height (2.092), biological yield per plot (0.494), days to maturity (0.355), 1000-seed weight (0.184), number of spikelets per spike (0.101) and number of tillers per plant (0.003). But, negative indirect effect via harvest index (-1.071), spike length (- 0.255), number of seeds per spikelet (-0.221), days to 50 $\%$ flowering (-0.155) and seed yield per plot (-0.154). Biological yield per plot exhibited positive indirect effect on seed yield per plant through plant height (2.521), number of seeds per spike (1.104), 1000-seed weight (0.477), days to maturity (0.316), number of spikelets per spike (0.193) and number of tillers per plant $(0.018)$ but negative indirect effect via., number of seeds per plant (-2.306), harvest index (-1.101), spike length (-0.693), seed yield per plot (-0.183), number of seeds per spikelet (-0.164) and days to $50 \%$ flowering (-0.095). Seed yield per plot exhibited positive indirect effect on 
seed yield per plant through plant height (2.908), number of seeds per spike (1.176), 1000-seed weight (0.701), biological yield per plot (0.664), days to maturity (0.343), number of spikelets per spike (0.154) and number of seeds per plant (0.021) but negative indirect effect via., number of seeds per plant (-2.604), harvest index (-1.239), spike length (-0.935), days to $50 \%$ flowering $(-0.095)$ and number of seeds per spikelet (-0.093). Harvest index exhibited positive indirect effect on seed yield per plant through plant height (3.358), 1000-seed weight (1.231), biological yield per plot (0.553), number of seeds per spike (0.439), days to maturity (0.299), number of seeds per spikelet $(0.173)$, number of spikelets per spike (0.094) and number of tillers per plant (0.033) but negative indirect effect via., number of seeds per plant (-2.509), spike length (-1.432), seed yield per plot (-0.172) and days to $50 \%$ flowering $(-0.045)$. Residual effect of 0.3174 exhibited that all the characters studied was sufficient to analyze their direct and indirect effects on seed yield per plant. A present, result confirms the finding of previous workers by Ali et al. (2008), Khan and Dar (2009) and Kumar et al. (2013).

\section{Phenotypic Path Coefficient Analysis}

The phenotypic path coefficients have been presented in table 2. At phenotypic level, considering seed yield per plant as dependent character, maximum positive direct effect is from number of tillers per plant (0.419) followed by number of seeds per spike (0.239), biological yield per plot (0.216), days to $50 \%$ flowering $(0.191)$, seed yield per plot (0.153), harvest index (0.151), number of seeds per plant (0.146), number of seeds per spikelet (0.135) and number of spikelets per spike (0.124). Whereas, negative direct effect on seed yield per plant via days to maturity $(-0.287)$, spike length (-0.218), 1000-seed weight (-0.029) and plant height (-0.020). The indirect effect had been explained for only those characters which had shown significant correlation values with seed yield per plant. Number of seeds per spike exhibited positive indirect effect on seed yield per plant through number of tillers per plant $(0.120)$, number of seeds per plant (0.086), biological yield per plot (0.057), number of seeds per spikelet (0.048), seed yield per plot (0.042), number of spikelets per spike (0.034), harvest index (0.013), days to maturity (0.016) and plant height $(0.002)$ but negative indirect effect via., spike length (-0.070) and days to $50 \%$ flowering (-0.059). Number of seeds per plant exhibited positive indirect effect on seed yield per plant through number of seeds per spike (0.141), biological yield per plot (0.119), days to maturity (0.107), seed yield per plot (0.091), harvest index (0.044), number of seeds per spikelet (0.031), spike length (0.024) and plant height (0.010) but negative indirect effect via., days to $50 \%$ flowering $(-0.093)$, number of spikelets per spike ($0.020)$, number of tillers per plant (-0.010) and 1000-seed weight (-0.002). Biological yield per plot exhibited positive indirect effect on seed yield per plant through seed yield per plot (0.118), days to maturity $(0.083)$, number of seeds per plant (0.081), number of seeds per spike (0.063), spike length (0.058), number of seeds per spikelet (0.030), harvest index (0.013) and plant height (0.010) but negative indirect effect via., days to $50 \%$ flowering (-0.051), number of spikelets per spike (-0.020), number of tillers per plant (-0.019) and 1000-seed weight (- 0.006). Seed yield per plot exhibited positive indirect effect on seed yield per plant through biological yield per plot (0.167), harvest index (0.103), days to maturity (0.095), number of seeds per plant (0.087), spike length (0.076), number of seeds per spike (0.065), number of seeds per spikelet (0.017) and plant height (0.015), but negative indirect effect via., number of tillers per plant (-0.108), days to $50 \%$ flowering (-0.055), number of spikelets per spike (-0.035) and 1000-seed weight (-0.009). Residual effect of 0.3084 exhibited that all the characters studied was sufficient to analyze their direct and indirect effects on seed yield per plant. Present results confirm the finding of previous worker Kumar et al. (2013). 


\section{REFERENCES}

1. Ali, Y., Atta, B.M., Akhter, J., Monneveux, P. and Lateef, Z. 2008. Genetic variability, association and diversity studies in wheat (Triticum aestivum L.)Germplasm. Pak. J. Bot., 40(5): 2087-2097.

2. Anonymous, 2013.Department of Economics and Statistics, Govt. of India.

3. Anonymous, 2014 a. FAO STAT and IGC Report, pp-1-3.

4. Anonymous, 2014 b. Department of Economics and Statistics, Govt. of India.

5. Choudhry, A.R., Shah, H.A. Ali, L. and Bashir, M. 1986. Path coefficient analysis of yield and yield components in wheat.Pak. J. Agric. Res., 7(2): 71-75.

6. Datta, S., Shukla S.N., Singh, S.S. and shoran, J. 2009.The Hind. Survey of Indian Agric., :41-42.

7. Degewione, A. Dejene, T. and Sharif, M. 2013. Genetic variability and traits association in bread wheat (Triticum aestivum L.) genotypes. International Re. J. of Agric. Sci., 1(2): 19-29.

8. Dewey, D.R., Lu, K.H. 1959. A correlation and path coefficient analysis of components of crested wheat grass seed production. Agronomy J., 51: 515-558.

9. Iftikhar, R., Khaliq,I., Ijaz, M. and Rashid, R.A.M. 2012.Association Analysis of Grain Yield and its Cmponents in Spring Wheat (Triticum aestivumL.). American-Eurasian J. Agric. \& Environ. Sci., 12 (3): 389-392.

10. Khan, H.M. and Dar, N.A.Correaltion and path coefficient analysis of some quantitative traits in wheat. 2009. African Crop Sci. J., $18(1): 9-14$.

11. Abd El-Aal, M. M. M. \& Zewail, R. M. Y, Shade Avoidance and Wheat (Triticum aestivum L.) Productivity, International Journal of Agricultural Science and Research (IJASR), Volume 4, Issue 3, May- June 2014, pp. 63-72

12. Khokhar, I. M., Hussain, M., Zulkiffal, M., Ahmad, N. and Sabar, W. 2010. Correlation and path analysis for yield and yield contributing characters in wheat (Triticum aestivumL.). African J. of Plant Sci., 4(11): 464-466.

13. Kumar, G., Singh, P.C., Singh, B. and Singh, D.K. 2013.Genetic variability inwheat (Triticum aestivumL.).Prog. Agric., 13(1): 239-242.

14. Majumder, D.A.N., Shamsuddin, A.K.M., Kabir, M.A. and Hassan, L. 2008. Genetic variability, correlated response and path analysis of yield and yield contributing traits of spring wheat.J. Bangladesh Agril. Univ.,6(2): 227-234.

15. Mohammad, T., Haider, S., Amin1, M., Khan, I.M. and Zamir R. 2005. Path coefficient and correlation studies of yield associated traits in candidate bread wheat (Triticum aestivum L.) lines. Suranaree J. Sci. Technol. 13(2): 175-180.

16. Nukasani, V., Potdukhe, N.R., Bharad, S., Deshmukh, S. and Shinde, S.M. 2013.Genetic variability, correlation and path analysis in wheat. J. of Wheat Res., 5(2): 48-51.

17. Rangare, N.R., Krupakar, A., Kumar. A. and Singh, S. 2013. Character association and component analysis in wheat (Triticum aestivum).Electronic J. of Plant Breeding, 1(3): 231-238.

18. Singh, B. J., Verma, A., Prakash, S., Patidar, I., TL, P., Prasad, S.V., Singh, K.A. and Mishra, N.A. 2013. Variability and interrelationship analysis in bread wheat under moisture stress conditions. J. Wheat Res. 5 (2): 27-34.

19. Wright, S. 1921. Correlation and causation. J. Agric. Res., 20: 557-558. 
Table1: Genotypic Path Coefficient Analysis Showing Direct and Indirect Effect of Different Yield Contributing Traits On Seed Yield(G) Plant ${ }^{-1}$

\begin{tabular}{|c|c|c|c|c|c|c|c|c|c|c|c|c|c|c|}
\hline & $\begin{array}{c}\text { Days } \\
\text { to } 50 \\
\% \\
\text { Flowe } \\
\text { ring }\end{array}$ & $\begin{array}{c}\text { Days to } \\
\text { Maturit } \\
y\end{array}$ & $\begin{array}{c}\text { Plant } \\
\text { Heig } \\
\text { ht } \\
(\mathrm{cm})\end{array}$ & $\begin{array}{l}\text { No. of } \\
\text { Tiller } \\
\text { s Per } \\
\text { Plant }\end{array}$ & $\begin{array}{c}\text { Spike } \\
\text { Lengt } \\
\text { h } \\
(\mathrm{cm})\end{array}$ & $\begin{array}{c}\text { No. of } \\
\text { Spike } \\
\text { lets } \\
\text { Per } \\
\text { Spike }\end{array}$ & $\begin{array}{c}\text { No. } \\
\text { of } \\
\text { Seeds } \\
\text { Per } \\
\text { Spike } \\
\text { lets }\end{array}$ & $\begin{array}{c}\text { No. of } \\
\text { Seeds } \\
\text { Per } \\
\text { Spike }\end{array}$ & $\begin{array}{c}\text { No. of } \\
\text { Seeds } \\
\text { Per } \\
\text { Plant }\end{array}$ & $\begin{array}{l}1000 \\
\text { Seed } \\
\text { Weig } \\
\text { ht }(\mathrm{g})\end{array}$ & $\begin{array}{c}\text { Biolo } \\
\text { gical } \\
\text { Yield } \\
\text { per } \\
\text { plots } \\
\text { (g) }\end{array}$ & $\begin{array}{c}\text { Seed } \\
\text { Yield } \\
\text { Per } \\
\text { Plot } \\
(\text { g) }\end{array}$ & $\begin{array}{c}\text { Harves } \\
t \text { index } \\
(\%)\end{array}$ & $\begin{array}{c}\text { genot } \\
\text { ypic } \\
\text { Corr } \\
\text { elatio } \\
\text { n } \\
\text { with } \\
\text { Seed } \\
\text { yield } \\
\text { Per } \\
\text { Plant } \\
\text { (g) }\end{array}$ \\
\hline $\begin{array}{l}\text { Days to } \\
50 \% \\
\text { flowerin } \\
\text { g }\end{array}$ & 0.28 & -0.676 & $\begin{array}{c}- \\
0.497\end{array}$ & -0.001 & -0.158 & -0.049 & 0.397 & $1.41^{-}$ & 1.752 & -0.135 & -0.231 & 0.064 & 0.217 & $\begin{array}{c}- \\
0.448 \\
*\end{array}$ \\
\hline $\begin{array}{l}\text { Days to } \\
\text { maturit } \\
y\end{array}$ & 0.218 & -0.868 & $\begin{array}{c}- \\
1.323\end{array}$ & -0.013 & 0.564 & -0.136 & 0.398 & -0.195 & 1.292 & -0.735 & -0.247 & 0.074 & 0.464 & $\begin{array}{c} \\
0.508 \\
*\end{array}$ \\
\hline $\begin{array}{l}\text { Plant } \\
\text { height } \\
(\mathrm{cm})\end{array}$ & 0.043 & -0.352 & 3.259 & -0.026 & 1.461 & -0.099 & 0.070 & -0.498 & 2.029 & -1.008 & -0.524 & 0.167 & 1.390 & $\begin{array}{c}- \\
0.746 \\
* *\end{array}$ \\
\hline $\begin{array}{l}\text { No. of } \\
\text { tillers } \\
\text { per } \\
\text { plant }\end{array}$ & 0.007 & -0.225 & $\begin{array}{c}- \\
1.637\end{array}$ & -0.052 & 1.371 & 0.072 & $\begin{array}{c}- \\
0.177\end{array}$ & 0.914 & 0.154 & -1.227 & -0.234 & 0.077 & 0.875 & $\begin{array}{c}- \\
0.083\end{array}$ \\
\hline $\begin{array}{l}\text { Spike } \\
\text { length } \\
(\mathrm{cm})\end{array}$ & -0.026 & -0.282 & 2.746 & -0.041 & 1.735 & -0.038 & $0 . \overline{100}$ & 1.090 & 0.465 & -1.375 & -0.271 & 0.101 & 1.114 & - \\
\hline $\begin{array}{l}\text { No. of } \\
\text { spikelet } \\
\text { s per } \\
\text { spike }\end{array}$ & 0.051 & -0.434 & $\begin{array}{c}- \\
1.184\end{array}$ & 0.014 & 0.243 & -0.271 & 0.110 & 0.171 & 1.177 & -0.462 & -0.481 & 0.106 & 0.469 & $\begin{array}{c}- \\
0.492 \\
*\end{array}$ \\
\hline $\begin{array}{l}\text { No. of } \\
\text { seeds } \\
\text { per } \\
\text { spikelet } \\
\text { s }\end{array}$ & -0.205 & 0.638 & 0.419 & -0.017 & 0.320 & 0.055 & $0 . \overline{542}$ & 1.621 & -1.289 & -0.136 & 0.205 & -0.032 & 0.430 & $\begin{array}{c}0.629 \\
* *\end{array}$ \\
\hline $\begin{array}{l}\text { No. of } \\
\text { seeds } \\
\text { per } \\
\text { spike }\end{array}$ & -0.119 & 0.051 & 0.488 & -0.014 & 0.568 & -0.014 & $\begin{array}{c}- \\
0.264\end{array}$ & 3.327 & -2.531 & -0.746 & 0.225 & -0.066 & -0.178 & $\begin{array}{c}0.726 \\
* *\end{array}$ \\
\hline $\begin{array}{l}\text { No. of } \\
\text { seeds } \\
\text { per } \\
\text { plant }\end{array}$ & -0.155 & 0.355 & 2.092 & 0.003 & -0.255 & 0.101 & 0.221 & 2.664 & -3.160 & 0.184 & 0.494 & -0.154 & -1.071 & $\begin{array}{c}0.877 \\
* *\end{array}$ \\
\hline $\begin{array}{l}1000 \\
\text { seed } \\
\text { weight } \\
\text { (g) }\end{array}$ & -0.021 & 0.363 & 1.868 & 0.036 & -1.357 & 0.071 & 0.042 & -1.412 & -0.331 & 1.758 & 0.184 & -0.075 & -0.944 & 0.182 \\
\hline $\begin{array}{l}\text { Biologic } \\
\text { al yield } \\
\text { per } \\
\text { plots (g) }\end{array}$ & -0.095 & 0.316 & 2.521 & 0.018 & -0.693 & 0.193 & 0.164 & 1.104 & -2.306 & 0.477 & 0.677 & -0.183 & -1.101 & $\begin{array}{c}0.764 \\
* *\end{array}$ \\
\hline $\begin{array}{l}\text { Seed } \\
\text { yield } \\
\text { per plot } \\
\text { (g }\end{array}$ & -0.095 & 0.343 & 2.908 & 0.021 & -0.935 & 0.154 & $\begin{array}{c}- \\
0.093\end{array}$ & 1.176 & -2.604 & 0.701 & 0.664 & -0.187 & -1.239 & $\begin{array}{c}0.813 \\
* *\end{array}$ \\
\hline $\begin{array}{l}\text { Harvest } \\
\text { index } \\
(\%)\end{array}$ & -0.045 & 0.299 & 3.358 & 0.033 & -1.432 & 0.094 & 0.173 & 0.439 & -2.509 & 1.231 & 0.553 & -0.172 & -1.349 & $\begin{array}{c}0.673 \\
*\end{array}$ \\
\hline
\end{tabular}

\section{Residual effect $=\mathbf{0 . 3 1 7 4}$}


Table2:.Phenotypic Path Coefficient Analysis Showing Direct and Indirect Effect of Different Yield Contributing Traits on Seed Yield (G) Plant ${ }^{-1}$

\begin{tabular}{|c|c|c|c|c|c|c|c|c|c|c|c|c|c|c|}
\hline & $\begin{array}{c}\text { Days to } \\
50 \% \\
\text { Floweri } \\
\text { ng }\end{array}$ & $\begin{array}{c}\text { Days } \\
\text { to } \\
\text { Maturi } \\
\text { ty }\end{array}$ & $\begin{array}{l}\text { Plant } \\
\text { Heig } \\
\text { ht } \\
(\mathrm{cm})\end{array}$ & 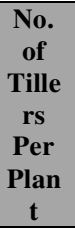 & $\begin{array}{c}\text { Spike } \\
\text { Leng } \\
\text { th } \\
(\mathrm{cm})\end{array}$ & $\begin{array}{l}\text { No. of } \\
\text { Spikel } \\
\text { ets Per } \\
\text { Spike }\end{array}$ & $\begin{array}{l}\text { No. of } \\
\text { Seeds } \\
\text { per } \\
\text { Spikel } \\
\text { ets }\end{array}$ & $\begin{array}{c}\text { No. } \\
\text { of } \\
\text { See } \\
\text { ds } \\
\text { Per } \\
\text { Spi } \\
\text { ke }\end{array}$ & $\begin{array}{c}\begin{array}{c}\text { No. } \\
\text { of } \\
\text { seed }\end{array} \\
\text { s } \\
\text { Per } \\
\text { Pla } \\
\text { nt }\end{array}$ & $\begin{array}{l}1000 \\
\text { Seed } \\
\text { Weig } \\
\text { ht }(\mathrm{g})\end{array}$ & $\begin{array}{c}\text { Biologi } \\
\text { cal } \\
\text { Yield } \\
\text { Per } \\
\text { Plots } \\
\text { (g) }\end{array}$ & $\begin{array}{c}\text { See } \\
\text { d } \\
\text { Yiel } \\
\text { d } \\
\text { Per } \\
\text { Plot } \\
\text { (g) } \\
\end{array}$ & $\begin{array}{c}\text { Harve } \\
\text { st } \\
\text { index } \\
(\%)\end{array}$ & $\begin{array}{l}\text { Phenoty } \\
\text { pic } \\
\text { Correlati } \\
\text { on with } \\
\text { Seed } \\
\text { Yield Per } \\
\text { Plant }(g)\end{array}$ \\
\hline $\begin{array}{l}\text { Days to } \\
50 \% \\
\text { floweri } \\
\text { ng }\end{array}$ & 0.191 & -0.217 & $\stackrel{-}{0.003}$ & $\begin{array}{c}0.01 \\
5\end{array}$ & 0.018 & 0.016 & -0.057 & $\begin{array}{c}- \\
0.07 \\
4\end{array}$ & $\begin{array}{c}- \\
0.07 \\
1\end{array}$ & 0.002 & -0.057 & $\begin{array}{c}- \\
0.04 \\
4\end{array}$ & -0.013 & -0.295 \\
\hline $\begin{array}{l}\text { Days to } \\
\text { maturit } \\
\text { y }\end{array}$ & 0.144 & -0.287 & $\begin{array}{c}- \\
0.007\end{array}$ & $\begin{array}{c}0.06 \\
9\end{array}$ & 0.060 & 0.038 & -0.053 & $\begin{array}{c}- \\
0.01 \\
3 \\
\end{array}$ & $\begin{array}{c}- \\
0.05 \\
4 \\
\end{array}$ & 0.012 & -0.062 & $\begin{array}{c}- \\
0.05 \\
0 \\
\end{array}$ & -0.025 & -0.351 \\
\hline $\begin{array}{l}\text { Plant } \\
\text { height } \\
(\mathrm{cm})\end{array}$ & 0.028 & -0.102 & 0.020 & $\begin{array}{c}0.17 \\
0\end{array}$ & $0 . \overline{138}$ & 0.032 & 0.001 & $\begin{array}{c}- \\
0.01 \\
8\end{array}$ & $\begin{array}{c}- \\
0.07 \\
1\end{array}$ & 0.015 & -0.109 & $\begin{array}{c}- \\
0.10 \\
9\end{array}$ & -0.081 & -0.403 \\
\hline $\begin{array}{l}\text { No. of } \\
\text { tillers } \\
\text { per } \\
\text { plant }\end{array}$ & 0.007 & -0.047 & 0.008 & $\begin{array}{c}0.41 \\
9\end{array}$ & 0.107 & 0.002 & 0.017 & $\begin{array}{c}0.06 \\
9\end{array}$ & $\begin{array}{c}- \\
0.00 \\
3\end{array}$ & 0.014 & -0.010 & $\begin{array}{c}- \\
0.03 \\
9\end{array}$ & -0.055 & 0.258 \\
\hline $\begin{array}{l}\text { Spike } \\
\text { length } \\
(\mathrm{cm})\end{array}$ & -0.016 & -0.079 & 0.013 & $\begin{array}{c}0.20 \\
7\end{array}$ & 0.218 & 0.029 & 0.028 & $\begin{array}{c}0.07 \\
7\end{array}$ & $\begin{array}{c}- \\
0.01 \\
6\end{array}$ & 0.020 & -0.058 & $\begin{array}{c}- \\
0.05 \\
3\end{array}$ & -0.041 & -0.133 \\
\hline $\begin{array}{l}\text { No. of } \\
\text { spikelet } \\
\text { s per } \\
\text { spike }\end{array}$ & 0.024 & -0.088 & 0.005 & $\begin{array}{c}0.00 \\
8\end{array}$ & $\begin{array}{c}- \\
0.052\end{array}$ & 0.124 & 0.013 & $\begin{array}{c}0.06 \\
5\end{array}$ & $\begin{array}{c}- \\
0.02 \\
3\end{array}$ & 0.005 & -0.045 & $\begin{array}{c}- \\
0.04 \\
3\end{array}$ & -0.029 & -0.048 \\
\hline $\begin{array}{l}\text { No. of } \\
\text { seeds } \\
\text { per } \\
\text { spikelet } \\
\text { S } \\
\end{array}$ & -0.081 & 0.113 & 0.000 & $\begin{array}{c}0.05 \\
4\end{array}$ & 0.045 & 0.012 & 0.135 & $\begin{array}{c}0.08 \\
4\end{array}$ & $\begin{array}{c}0.03 \\
4\end{array}$ & 0.002 & 0.048 & $\begin{array}{c}0.01 \\
9\end{array}$ & -0.015 & 0.360 \\
\hline $\begin{array}{l}\text { No. of } \\
\text { seeds } \\
\text { per } \\
\text { spike }\end{array}$ & -0.059 & 0.016 & 0.002 & $\begin{array}{c}0.12 \\
0\end{array}$ & 0.070 & 0.034 & 0.048 & $\begin{array}{c}0.23 \\
9\end{array}$ & $\begin{array}{c}0.08 \\
6\end{array}$ & 0.010 & 0.057 & $\begin{array}{c}0.04 \\
2\end{array}$ & 0.013 & $0.538 * *$ \\
\hline $\begin{array}{l}\text { No. of } \\
\text { seeds } \\
\text { per } \\
\text { plant }\end{array}$ & -0.093 & 0.107 & 0.010 & $\begin{array}{c}- \\
0.01 \\
0\end{array}$ & 0.024 & -0.020 & 0.031 & $\begin{array}{c}0.14 \\
1\end{array}$ & $\begin{array}{c}0.14 \\
6\end{array}$ & 0.002 & 0.119 & $\begin{array}{c}0.09 \\
1\end{array}$ & 0.044 & $0.589 * *$ \\
\hline $\begin{array}{l}1000 \\
\text { seed } \\
\text { weight } \\
\text { (g) }\end{array}$ & -0.014 & 0.117 & 0.011 & $\begin{array}{c}- \\
0.19 \\
7\end{array}$ & 0.151 & -0.021 & -0.010 & $\begin{array}{c}- \\
0.08 \\
2\end{array}$ & $\begin{array}{c}0.01 \\
2\end{array}$ & 0.029 & 0.041 & $\begin{array}{c}0.04 \\
9\end{array}$ & 0.050 & 0.077 \\
\hline $\begin{array}{l}\text { Biologi } \\
\text { cal } \\
\text { yield } \\
\text { per } \\
\text { plots } \\
\text { (g) }\end{array}$ & -0.051 & 0.083 & 0.010 & $\begin{array}{c}- \\
0.01 \\
9\end{array}$ & 0.058 & -0.026 & 0.030 & $\begin{array}{c}0.06 \\
3\end{array}$ & $\begin{array}{c}0.08 \\
1\end{array}$ & 0.006 & 0.216 & $\begin{array}{c}0.11 \\
8\end{array}$ & 0.013 & $0.571 * *$ \\
\hline $\begin{array}{l}\text { Seed } \\
\text { yield } \\
\text { per plot } \\
\text { (g) }\end{array}$ & -0.055 & 0.095 & 0.015 & $\begin{array}{c}- \\
0.10 \\
8\end{array}$ & 0.076 & -0.035 & 0.017 & $\begin{array}{c}0.06 \\
5\end{array}$ & $\begin{array}{c}0.08 \\
7\end{array}$ & 0.009 & 0.167 & $\begin{array}{c}0.15 \\
3\end{array}$ & 0.103 & $0.570^{* *}$ \\
\hline $\begin{array}{l}\text { Harvest } \\
\text { index } \\
(\%)\end{array}$ & -0.016 & 0.047 & 0.011 & $\begin{array}{c}- \\
0.15 \\
3\end{array}$ & 0.060 & -0.024 & -0.013 & $\begin{array}{c}0.02 \\
1\end{array}$ & $\begin{array}{c}0.04 \\
2\end{array}$ & $\stackrel{-}{0.010}$ & 0.018 & $\begin{array}{c}0.10 \\
4\end{array}$ & 0.151 & 0.239 \\
\hline
\end{tabular}

Residual Effect $=0.3084$ 